University of Nebraska - Lincoln

DigitalCommons@University of Nebraska - Lincoln

Agronomy \& Horticulture -- Faculty Publications

Agronomy and Horticulture Department

July 1982

Respiration, Carbohydrate Content, and Leaf Growth of Tall

Fescue

Lowell E. Moser

University of Nebraska-Lincoln, Imoser1@unl.edu

J. J. Volenec

Univ. of Missouri-Columbia, Columbia, MO

C. J. Nelson

University of Nebraska-Lincoln

Follow this and additional works at: https://digitalcommons.unl.edu/agronomyfacpub

Part of the Plant Sciences Commons

Moser, Lowell E.; Volenec, J. J.; and Nelson, C. J., "Respiration, Carbohydrate Content, and Leaf Growth of Tall Fescue" (1982). Agronomy \& Horticulture -- Faculty Publications. 90.

https://digitalcommons.unl.edu/agronomyfacpub/90

This Article is brought to you for free and open access by the Agronomy and Horticulture Department at DigitalCommons@University of Nebraska - Lincoln. It has been accepted for inclusion in Agronomy \& Horticulture -Faculty Publications by an authorized administrator of DigitalCommons@University of Nebraska - Lincoln. 


\title{
Respiration, Carbohydrate Content, and Leaf Growth of Tall Fescue ${ }^{1}$
}

\author{
L. E. Moser, J. J. Volenec, and C. J. Nelson ${ }^{2}$
}

\begin{abstract}
Tall fescue (Festuca arundinacea Schreb.) was grown in controlled environment chambers with a 14-hour photoperiod, and then kept in darkness for 8 days in one experiment and 20 days in another. The objectives were to determine concentrations of total nonstructural carbohydrates (TNC) and relate them to leaf elongation rates (LER) and to rates of dark respiration $\left(R_{D}\right)$. After various times in darkness, leaf terminal meristems in vegetative tillers, root tips, and center-sections of collared leaf blades were excised, and oxygen consumption was measured.

Oxygen consumption was generally highest in terminal meristems, intermediate in root tips, and lowest in mature leaf blades. For the first 6 days the daily LER was greater in plants growing in darkness compared with those in 14-hour photoperiods. From 6 to 12 days of darkness, LER was similar on both sets of plants. After 12 days the dark-grown plants had lower LER. By extrapolation of the $L E R / R_{D}$ relationship to zero LER, maintenance respiration of leaf terminal meristems was estimated to be about $0.95 \mu \mathrm{l} 0_{2} \cdot \mathrm{mg}$ structural dry weight $(\mathrm{SDW})^{-1} \cdot$ hour $^{-1}$, which represented $24 \%$ of the oxygen consumed. Collared leaf segments approached maintenance levels of $\mathbf{R}_{\mathrm{v}}$ after 2 days of darkness and root tips after 8 days. However, terminal meristems had a high TNC concentration and continued to support leaf growth actively for up to 16 days of darkness. The $R_{\mathrm{D}}$, TNC, and LER were all directly associated.

\footnotetext{
Contribution from the Dep. of Agronomy, Univ. of Missouri-

${ }^{2}$ Professor of agronomy, Univ. of Nebraska-Lincoln, graduate assistnical assistance.
} Columbia, Columbia, MO 65211. Approved for publication by the Director of the Missouri Agric. Exp. Stn. as Research Paper No. 8780. Received 5 May 1981. ant and professor, Dep. of Agronomy, Univ. of Missouri-Columbia, respectively. This research was conducted while the senior author was on sabbatic leave at the Univ. of Missouri-Columbia. The authors would like to express sincere appreciation to Mr. John Coutts for valuable tech-
\end{abstract}

Maximum $\mathbf{R}_{\mathrm{D}}$ in terminal meristems occurred at $35 \%$ TNC while LER remained similar when TNC levels were higher than $28 \%$. In mature leaf tissue about $60 \%$ of the oxygen consumption was associated with maintenance respiration.

Additional index words: Maintenance respiration, Growth respiration, Leaf elongation, Festuca arundinacea Schreb.

TEnTIFICATION of physiological and morphological $\mathbf{l}$ characteristics of forage grasses related to dry matter production may assist plant breeders in their efforts to improve forage yield. In tall fescue (Festuca arundinacea Schreb.), a poor correlation exists between $\mathrm{CO}_{2}$ exchange rate of single leaves and forage yield (Nelson et al., 1975). Horst et al. (1978) determined that leaf elongation rate (LER) was positively correlated with forage yield. Wilhelm and Nelson (1978) suggested that preferential utilization of assimilate for leaf growth during the first 16 days of regrowth was in part responsible for the rapid LER observed. Physiological processes such as partitioning and utilization of photosynthate may be more important in influencing yield of tall fescue than is the rate of carbon assimilation of single leaves.

Relationships between dark respiration $\left(R_{D}\right)$ and whole plant growth rates have been examined assuming two components of $\mathrm{R}_{\mathrm{D}}$ (Thornley, 1970; McCree, 1970). The maintenance component is proportional to plant biomass and appears to be independent of substrate concentration 
(Penning de Vries, 1974). Several methods of determining the components of $R_{D}$ have been suggested, both experimental (McCree, 1970; Yokoi et al., 1978) and empirical (Thornley, 1970, 1977; Penning de Vries, 1975). Variation in $R_{D}$ components exists between species (McCree, 1974; Ryle et al., 1976; Yokoi et al., 1978; Kimura et al., 1978; Lambers, 1979), and between plant parts of the same species (Hansen and Jensen, 1977; Hansen, 1978; Jones and Nelson, 1979; Lambers et al., 1979). Plant age (Lambers, 1979) and mineral nutrition (Hansen, 1979; Lambers, 1979) also influence respiration components.

Attempts to determine growth and maintenance components of $R_{D}$ of leaf terminal meristems by placing the plants in darkness for 48 hours were not successful with tall fescue because substrate concentrations did not decline to a level that lowered $R_{D}$ (Jones and Nelson, 1979). The terminal meristem evidently imported substrate (Robson and Parsons, 1981). Yemm (1965) and Challa (1976) showed that $R_{D}$ of leaf tissue was not dependent on substrate supply when carbohydrate concentrations exceeded critical levels. Robson and Parsons (1981) reported that the $\mathrm{R}_{\mathrm{D}}$ of meristematic areas of uniculm barley (Hordeum vulgare L.) fell sharply after 12 hours of darkness. After 80 hours of darkness the rate of $R_{D}$ was still three times that of mature leaf tissue. Mature leaf tissue reached a steady state of $\mathrm{CO}_{2}$ efflux (2.0 to $2.5 \mathrm{mg} \mathrm{CO}{ }_{2} \cdot \mathrm{g}^{-1} \cdot$ hour $^{-1}$ ) after about 12 hours of darkness.

Genetic variation exists for $R_{D}$ for root tips, leaf blades, and leaf terminal meristems of tall fescue genotypes selected for a range in yield/tiller (Jones and Nelson, 1979). Wilson (1975) suggested that maintenance respiration may be an important determinant of genotypic differences in growth rate in Lolium genotypes.

Our objectives were to determine respiration rates of tall fescue root tips, collared leaf blades, and leaf terminal meristems. Our effort focused on following trends in leaf growth, $\mathrm{R}_{\mathrm{D}}$, and total nonstructural carbohydrates (TNC) of established plants grown in continuous darkness for 8 and 20 days and relating them to leaf elongation rate.

\section{MATERIALS AND METHODS}

Experiment I Rates of $\mathrm{R}_{\mathrm{D}}$ and concentrations of TNC were measured during 8 days of continuous darkness. Plastic pots, 10 $\mathrm{cm}$ wide by $15 \mathrm{~cm}$ deep, were filled with a soil mixture consisting of Mexico silt loam top soil (Udollic Ochraqualf), peat, and coarse sand in a 2:1:1 ratio. Each pot had four 3-mm holes in the bottom to permit drainage. Three vegetative tillers of a medium yield/tiller (MYT) genotype selected by Jones et al. (1979) were transplanted into each pot in June 1978. Plants were grown in a greenhouse at $25 \pm 5 \mathrm{C}$. During establishment pots were watered biweekly with $50 \mathrm{ml}$ nutrient solution containing 189,38 , and $151 \mathrm{mg} / \mathrm{liter}$ of $\mathrm{N}, \mathrm{P}$, and $\mathrm{K}$, respectively. Herbage was cut and discarded, leaving a $5-\mathrm{cm}$ stubble at approximately 6-week intervals.

On 15 Feb. 1979 the herbage of plants in 20 pots was cut to a 5 -cm stubble and discarded, and the pots transferred to a controlled environment chamber programmed at 25/20 C (photoperiod/dark period). Relative humidity was maintained between 50 and $70 \%$, and a 14-hour photoperiod of $500 \mu \mathrm{E} \cdot \mathrm{m}^{-2} \cdot \mathrm{sec}^{-1}$ photosynthetic photon flux density at the canopy level was provided by cool-white fluorescent and incandescent bulbs. Plants received distilled water as needed, and $50 \mathrm{ml}$ of Hoagland's complete nutrient solution biweekly. Plants were allowed to regrow and become acclimated to chamber conditions for 4 weeks prior to sampling. Plants remained vegetative.

On 15 March 1979 the plants were blocked into four replicates. Three hours into the photoperiod the following tissue samples were obtained from a pot in each replicate: (i) two $2-\mathrm{cm}$ segments of the center portions of two leaf blades that had collared recently; (ii) approximately $100 \mathrm{mg}$ fresh weight of root tips, $2.5 \mathrm{~cm}$ in length; (iii) approximately $100 \mathrm{mg}$ fresh weight from the leaf terminal meristem area ( 7 to 11 terminal meristems, approximately). The latter tissue was obtained by stripping sheath material from the leaf terminal area, including the sheath of the last collared leaf. The leaf terminal area was then cut from the plant crown at the point of attachment of the sheath of the last collared leaf. The elongating leaf blades were removed $3 \mathrm{~mm}$ above the same point to give a tissue sample consisting of the terminal meristem and the lower $3 \mathrm{~mm}$ of the intercalary meristem region of the elongating leaves.

Samples were floated on $2 \mathrm{ml}$ of deionized water in the outer well of $17 \mathrm{ml}$ single-sidearm Gilson respirometer flasks. Flasks with leaf segments were wrapped in aluminum foil to shield the samples from light. $\mathrm{A} \mathrm{CO}_{2}$-free atmosphere was maintained in the flask by absorption of $\mathrm{CO}_{2}$ by $0.2 \mathrm{ml}$ of $20 \% \mathrm{KOH} \mathrm{(w/v)}$ placed on a filter paper wick in the center well. Flasks and tissues were equilibrated in a $25 \mathrm{C}$ water bath for 1 hour before $\mathrm{O}_{2}$ uptake was measured at 30 -min intervals over a 2-hour period. After $\mathrm{O}_{2}$ uptake measurements were complete, tissues were removed from the flasks, dried at $70 \mathrm{C}$ for 48 hours and weighed. Samples of each tissue were also removed simultaneously from pots for measurements of total nonstructural carbohydrate (TNC) concentrations at the same time as the tissue used in the respiration measurement. Tissue was dried immediately at $70 \mathrm{C}$ and then ground. The TNC was hydrolyzed with Clarase 900 (Miles Laboratories) and reducing power of the hydrolysate was determined by the copper-oxidation iodine titration method of Smith (1969). Rate of $R_{D}$ and percentage of TNC were expressed on a structural dry weight basis (SDW, dry weight minus TNC).

After sampling tissue for $R_{D}$ and TNC estimates during the normal photoperiod the lights were turned off and the dark period maintained for the next 8 days. Measurements of $R_{D}$ and TNC were obtained on the same tissue types $2,4,6$, and 8 days into the extended dark period. Our hypothesis was that 8 days of darkness could deplete stored carbohydrates and reduce growth to such a point that an estimate of maintenance $R_{D}$ could be made.

Experiment $I I$. Information from Exp. I indicated that an 8-day treatment was insufficient to reduce $R_{D}$ in leaf terminal meristems and reduce leaf elongation. Therefore, in Exp. II $R_{1}$ and TNC concentrations were measured during 20 days of continuous darkness. Again, the objective was to reduce TNC to concentrations that would limit growth, thus allowing estimation of maintenance $R_{D}$. Forty pots containing the MYT genotype established at the same time and in a similar manner as the plants described earlier, were cut to a $5-\mathrm{cm}$ stubble and placed in the controlled environment chamber described, on 19 April 1979. Environmental conditions, watering, and fertilization were the same as described above. Following a 4-week acclimation period plants were arranged into four replicates and measurements of $R_{D}$ rates and TNC concentrations commenced.

The first measurements of TNC concentrations and $R_{D}$ rates were taken approximately 3 hours into the photoperiod of a nor$\mathrm{mal}$ photoperiod/dark period cycle. Thirty-two pots of plants were maintained in continuous darkness at $22 \mathrm{C}$ for the next 20 days. Four pots of plants were transferred into a second controlled environment chamber with photoperiod and other conditions identical to those of the original controlled environmental 
chamber. Rates of $R_{D}$ and TNC concentrations were measured on these light-grown plants 19 days later. Rates of $R_{D}$ and TNC concentrations were measured as described in Exp. I. Leaf elongation rate (LER) was estimated by measuring daily the leaf length of a growing leaf from the tip to the collar of the previous collared leaf of plants used for the Day 16 and Day 20 sampling. For comparison, LER of the light-grown plants used for $R_{D}$ sampling on Day 19 was also measured throughout the experimental period.

Statistical Analysis. Oxygen consumption as measured in the 2hour period was plotted against time and a linear regression line was fit. The slope of the regression line was corrected for $\mathrm{O}_{2}$ absorption by the deionized water and was considered to be the rate of $R_{D}$. Tissues in Replicates 1 and 2, and in Replicates 3 and 4 were combined to provide sufficient material for TNC analysis. For comparisons where the F-test was significant $(p \leq 0.05)$, L.S.D.'s were calculated.

\section{RESULTS AND DISCUSSION}

In Exp. I rates of $R_{D}$ of root tips declined $71 \%$ (p $\leq 0.05$ ) during the 8 days of continuous darkness, while rates of $R_{D}$ of both mature leaf blades and leaf terminal meristem areas (where leaves are initiated) were not diminished significantly (Fig. 1). Initially, rates of $R_{D}$ were highest in root tips and leaf terminal meristems and lowest in leaf blades. The rate of $R_{D}$ for leaf terminal meristems was higher than that reported by Jones and Nelson (1979) perhaps because more mature sheath material had been removed from the terminals in our experiments. Rates of $R_{D}$ for other tissues in our experiments agreed in general with those of Jones and Nelson (1979).

Concentrations of TNC declined significantly ( $p$ $\leq 0.05)$ in both leaf terminal meristems $(62 \%)$ and root tips (86\%) during 8 days of continuous darkness (Fig. 1). The $67 \%$ decline in TNC concentration of leaf blades during the experiment was significant at $p \leq 0.10$. Con- centrations of TNC were greatest in leaf terminal meristems, intermediate in leaf blades, and lowest in root tips.

In Exp. II rates of $R_{D}$ declined 68,49 , and $71 \%$ in leaf blades, leaf terminal meristems and root tips, respectively, during the 20 days in continuous darkness (Fig. 1). Rates of $R_{D}$ of both leaf blades and root tips had decreased after 2 days of darkness, but decline in $R_{D}$ of leaf terminal meristems was not observed until after day 4 . Highest rates of $R_{D}$ were found in leaf terminal meristems and lowest in leaf blades, while intermediate rates were found in root tips.

During Exp. II, concentrations of TNC declined 95, 82, and $96 \%$ for leaf blades, terminal meristems and root tips, respectively (Fig. 1). The pattern of TNC decline was similar in all three tissues measured, beginning the first day following the onset of darkness. As in Exp. I, highest concentrations of TNC were found in leaf terminal meristems, lowest in root tips, with leaf blades intermediate.

Concentrations of TNG and rates of $R_{D}$ of leaf terminal meristems on day 19 of the plants remaining in the normal photoperiod were similar to those of the plants harvested on day zero (Fig. 1). Concentrations of TNC and rates of $R_{D}$ were slightly higher in root tips of light-grown plants, while TNC concentrations of leaf blades of the light-grown plants had declined slightly when compared with plants harvested on Day zero.

Since $R_{D}$ in collared leaf tissue declined very little, especially after 48 hours of darkness, maintenance respiration is evidently the main component. Forty-eight hours of darkness may be adequate to separate maintenance from growth respiration that may be associated with secondary thickening of cell walls and increase in specific leaf weight even though the TNC level continued to decline until the 8th day. The decline in TNC or $R_{D}$ in any of the actively growing plant parts had not leveled off after 48

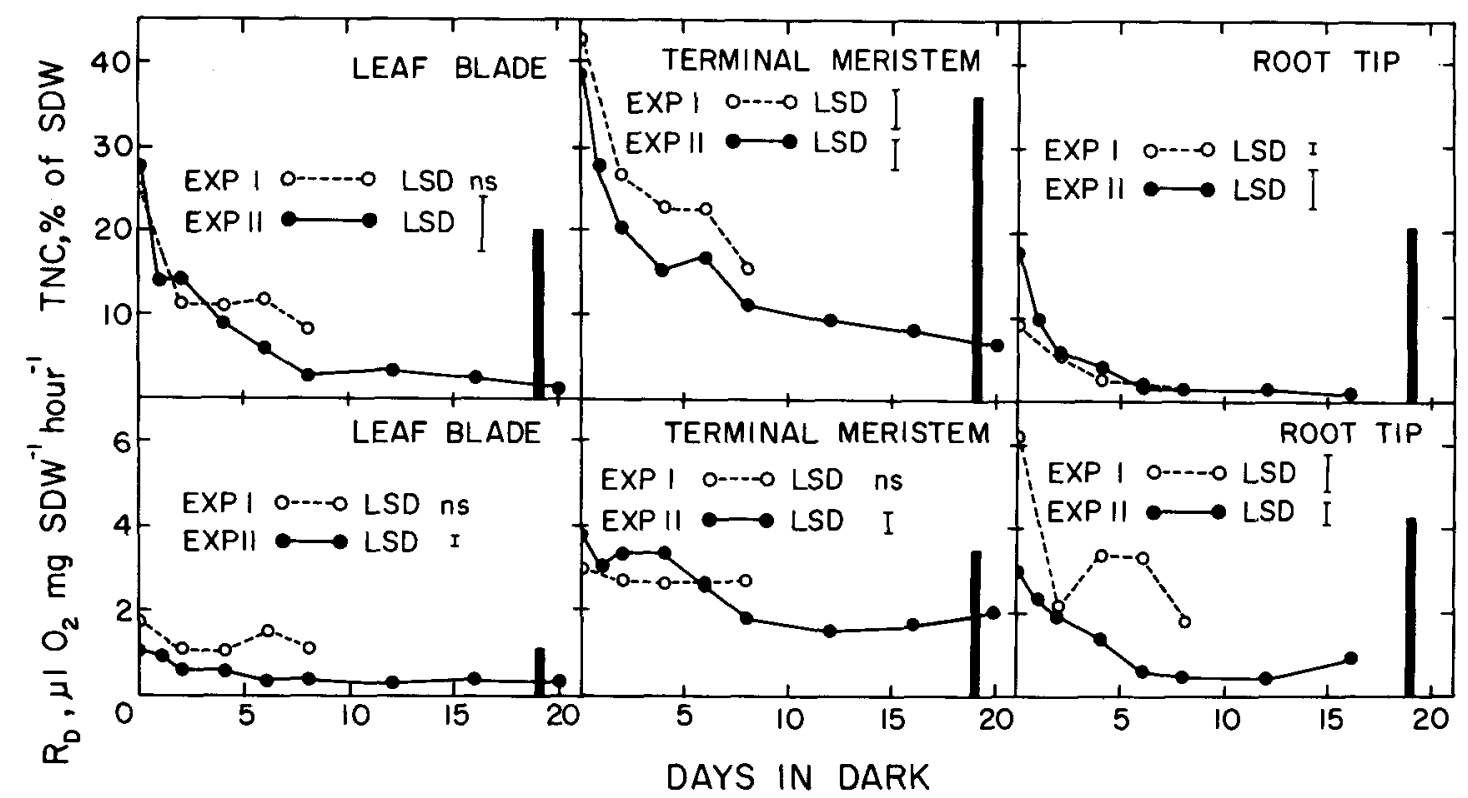

Fig. 1. Trends of dark respiration $\left(R_{\mathrm{D}}\right)$ and total nonstructural carbohydrates (TNC) of tall fescue leaf blades, leaf terminal meristems and root tips of plants grown in continuous darkness for 8 (Exp. I) and 20 (Exp. II) days. Least significant differences (LSD) at $p \leq 0.05$ are for
comparison within an experiment. Bars show values for plants kept in normal photoperiod. 


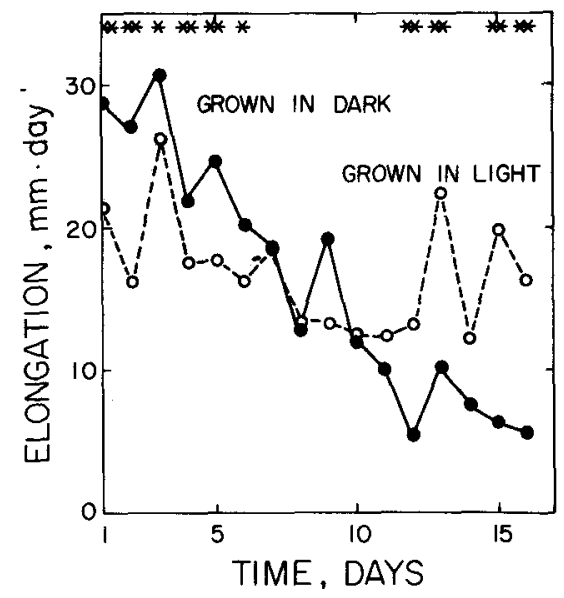

Fig. 2. Leaf elongation rate (LER) of tall fescue tillers grown in the light and dark for 20 days. Asterisks ( ${ }^{*}$ and ${ }^{* *}$ ) denote significant differences in LER ( $p \leq 0.05$, and 0.01 , respectively) between light- and dark-grown plants.

hours in darkness. Therefore, separation of maintenance from growth respiration for these tissues could not be attempted at that time as concluded by Jones and Nelson (1979). The TNC in the leaf terminal meristems continued to decline throughout the duration of these experiments. Matches (1969) has shown that herbage regrowth of tall fescue continued during 6 weeks of continuous darkness. The leaf terminal meristem area is probably a strong sink in the plant since carbohydrate in stem bases was apparently translocated to the meristems throughout the duration of Exp. II. On the 16th day of darkness most of the root tips were brown and apparently dead. The few root tips, that were white and apparently alive, were selected for $R_{D}$ measurements so the respiration rate of root tips raised slightly on the 16th day compared with the 12th day of darkness where no selection of root tips occurred. Root tips expired more quickly than did leaf terminal meristems with the extended dark period. Evidently leaf terminal meristems were supplied with carbohydrates for a longer period of time than the root tips.

Leaf elongation rate (LER) of plants growing in continuous darkness averaged $34 \%$ higher than did those of light-grown plants during the first 6 days of Exp. II (Fig. 2). Rates of leaf elongation of the light- and dark-grown plants were similar from Day 7 to Day 11, after which LER of the light-grown plants exceeded that of the darkgrown plants. Total elongation for the 16-day period was 269 and $248 \mathrm{~mm}$ for the light and dark treatments, respectively. The decline in LER of light-grown plants from Day 8 to Day 12 was due in part to slow rates of leaf growth as measured leaves formed collars and measurements commenced on the newly-emerged leaves. Under normal photoperiod conditions LER of tall fescue in darkness exceeded that in light (Volenec and Nelson, 1982), which probably accounts for the rapid LER by the darkgrown plants early in the experiment.

Leaf elongation requires an adequate supply of carbohydrates for use as biosynthetic precursors, and for oxidation to produce energy. Since double reciprocal plots of LER and TNC did not yield a straight line the relation-

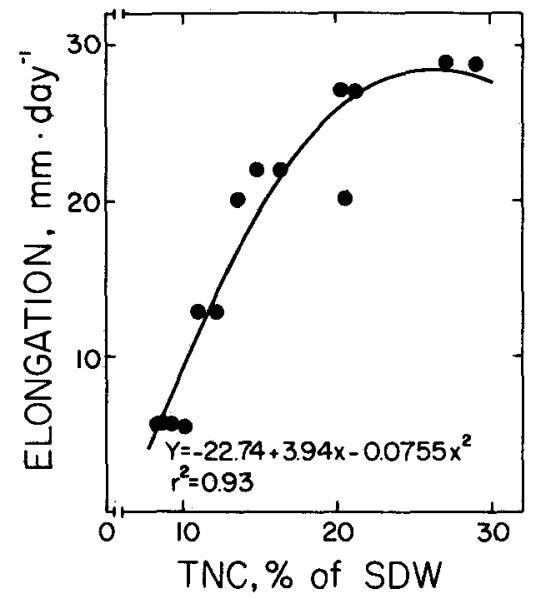

Fig. 3. Relationship between tall fescue leaf elongation rate (LER) and total nonstructural carbohydrate (TNC) concentrations of leaf terminal meristems. Exp. II.

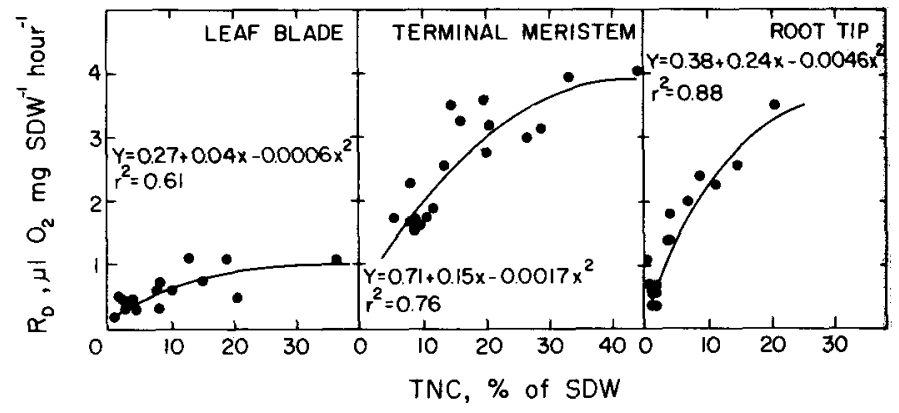

Fig. 4. Relationship between dark respiration $\left(R_{D}\right)$ and total nonstructural carbohydrate (TNC) concentrations of tall fescue leaf blades, leaf terminal meristems and root tips. Exp. II.

ship between LER and TNC of the leaf terminal meristem areas for the dark-grown plants was best described by a quadratic equation in a range of about 8 to $26 \%$ TNC (Fig. 3). A minimum leaf terminal meristem TNC concentration of around $26 \%$ was required for maximum LER to occur in this genotype. Other research has also shown that high concentrations of water-soluble carbohydrate were associated with high LER (Jones and Nelson, 1979; Penning de Vries et al., 1979). Moreover, Lambers (1979) concluded that root growth rate and level of soluble carbohydrate in the roots may be more important factors than respiration efficiency in determining total plant growth.

In addition to $L E R$, the $R_{D}$ of the leaf terminal meristem area was related to TNC concentration (Fig. 4). A curvilinear relationship existed between $R_{D}$ and TNC level in leaf terminal meristems, root tips, and to a lesser extent in mature leaf blade tissue (Fig. 4). Cunningham and Syvertsen (1977) showed a curvilinear relationship between dark $\mathrm{CO}_{2}$ release and TNC concentration in creosotebush (Larrea tridentata DC Cov.) although they were dealing with lower TNC levels. Challa (1976) reported a positive linear relationship between rate of $R_{D}$ and sugar concentration of winter grown cucumber ( $\mathrm{Cuc}$ - 


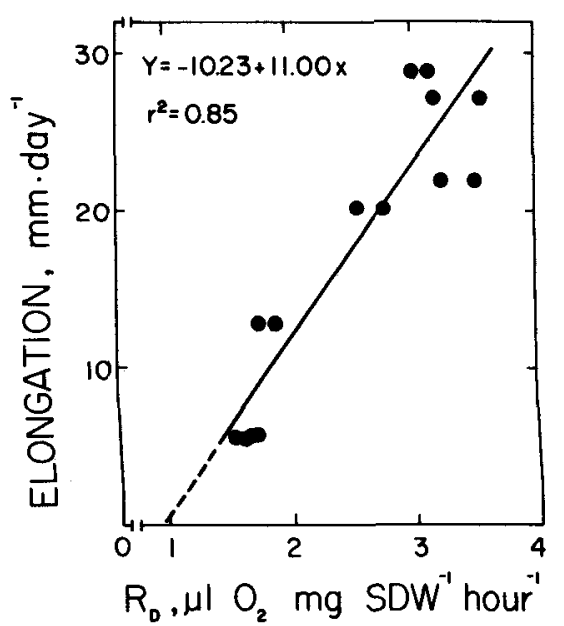

Fig. 5. Relationship between tall fescue leaf elongation rate (LER) and rate of leaf terminal meristem dark respiration $\left(R_{b}\right)$. Exp. II.

umis sativus L.) leaves. Leaves of spring grown plants contained two-fold higher sugar concentrations and rates of $R_{D}$ were influenced less by fluctuations in sugar content. Rates of $R_{D}$ of leaf terminal meristems declined when meristem TNC concentration was less than about $35 \%$ of SDW, although LER was not reduced until leaf terminal meristem TNC concentration dropped below about $26 \%$ of SDW (Fig. 3). Initially a more than adequate supply of TNC to support respiration for maximum LER was present in the leaf terminal meristem area and would not be expected to be reduced quickly during the short dark period for plants that are in a normal diurnal light situation.

Root tip $R_{D}$ rates were also affected dramatically by tissue TNC concentration (Fig. 4) since both growth and maintenance $R_{D}$ were occurring in this growing tissue. Collared leaf blade $R_{D}$ rates were influenced by TNG concentrations less than were the growing tissues mentioned earlier, being independent of the TNC concentration in excess of $20 \%$. Presumably maintenance $R_{D}$ was predominant in this tissue. Coggeshall and Hodges (1980) reported that in soybeans [Glycine $\max \left(\mathrm{L}\right.$.) Merrill] $\mathrm{R}_{\mathrm{D}}$ was correlated positively with carbohydrate content in tissues where growth respiration predominated and correlated poorly in tissue where maintenance respiration predominated.

Penning de Vries et al. (1979) indicated that leaf elongation rate may not be a good indicator of yield in ryegrass (Lolium spp.), but Horst et al. (1978) indicated that LER was correlated positively with yield of tall fescue. Jones et al. (1979) have also reported that a high LER was associated with high yield per tiller. Day-to-day variation in the LER of Fig. 2 was probably caused by mild water stresses and effects of nutrient solution additions which Penning de Vries et al. (1979) indicated were important factors affecting LER. The LER also decreased as one leaf collared and the subsequent leaf began growth.

A positive linear relationship existed between LER and $R_{D}$ rates of leaf terminal meristems of tall fescue grown in continuous darkness for 16 days (Fig. 5). The positive slope indicates higher LER may be attained with increases in leaf terminal meristem $R_{D}$. This is in agreement with the literature (Jones and Nelson, 1979; Kimura et al., 1978; Penning de Vries et al. 1979) in that a large amount of growth respiration would be involved in synthesis of new tissue. Alternatively Wilson (1975) reported that growth of genotypes of ryegrass with slow leaf blade respiration (largely maintenance) was faster than those with rapid respiration. This points out the importance of delineating growth and maintenance respiration in plant improvement.

Maintenance respiration and zero growth are difficult to measure in leaf terminal meristems because stored carbohydrates continue to be translocated into the meristems maintaining metabolic activity and growth (Fig. 1 and 2). Therefore the linear regression relating LER and leaf terminal meristem $R_{D}$ was extrapolated to a zero growth rate (Fig. 5). The intercept of the line on the horizontal axis at $0.95 \mu \mathrm{l} \mathrm{O}_{2} \cdot \mathrm{mgSDW}^{-1} \cdot$ hour $^{-1}$ is theoretically an estimate of the maintenance component of $R_{D}$. Using a respiratory quotient of 1.0 this would be $1.87 \mathrm{mg} \mathrm{CO} \mathrm{mSW}^{-1}$. hour $^{-1}$. The rate compares favorably with values obtained by Penning de Vries et al. (1979) and Lambers et al. (1979), although it is somewhat lower than that reported by Lambers (1979) after the appropriate conversions are made to allow comparison.

The mean total (maintenance + growth) $R_{D}$ rate for leaf terminal meristems prior to the onset of continuous darkness (day zero) was $3.99 \mu \mathrm{l} \mathrm{O}_{2} \cdot \mathrm{mgSDW}^{-1} \cdot$ hour $^{-1}$ (Fig. 1). The maintenance respiration estimate of $0.95 \mu \mathrm{l}$ $\mathrm{O}_{2} \cdot \mathrm{mgSDW}^{-1} \cdot$ hour $^{-1}$ indicates that $24 \%$ of the oxygen consumed was associated with maintenance respiration. If steady state $R_{D}$ of collared leaf blades after 48 hours or longer in darkness is considered to be maintenance respiration, a value of approximately $1.0 \mu \mathrm{l} \mathrm{O}_{2} \cdot \mathrm{mgSDW}^{-1}$. hour $^{-1}$ is obtained in Exp. I which is similar to the extrapolated $0.95 \mu \mathrm{l} \mathrm{O}_{2} \cdot \mathrm{mgSDW}^{-1} \cdot$ hour $^{-1}$. During the first 8 days in Exp. II a smaller value would be obtained due to lower $R_{D}$ rates (Fig. 1). In collared leaf blade tissue in both experiments there was about a $40 \%$ reduction in the $R_{D}$ rates after 2 days of darkness compared to when the experiment began. This would indicate that about $60 \%$ of the oxygen uptake of collared leaf blades was associated with the maintenance component.

It is apparent that tissues differ in their respiration rates and growth to maintenance relationships. Selecting for a low rate of mature tissue respiration after an extended dark period as suggested by Robson and Parsons (1981) may prove useful in improving tall fescue yield through breeding. Selection programs have been effective in decreasing respiration of collared leaf blades and improving plant performance (Wilson, 1975), but whether this response occurred genetically independent from respiratory control in meristematic areas remains to be determined. The high carbohydrate content of storage tissues makes assessment of growth respiration of many tissues more difficult.

\section{REFERENCES}

1. Challa, H. 1976. An analysis of the diurnal course of growth, carbon dioxide exchange and carbohydrate reserve content of cucumber. Agric. Res. Rep. 861. Centre for Agrobiological Research, Wageningen. 
2. Coggeshall, B. M., and H. F. Hodges. 1980. The effect of carbohydrate concentration on the respiration rate of soybean. Crop Sci. 20:86-90.

3. Cunningham, G. L., and J. P. Syvertsen. 1977. The effect of nonstructural carbohydrate levels on dark $\mathrm{CO}_{2}$ release in creosotebush. Photosynthetica 11:291-295.

4. Hansen, G. K. 1978. Utilization of photosynthates for growth, respiration, and storage in tops and roots of Lolium multiforum. Physiol. Plant. 42:5-13.

5. ---. 1979. Influence of nitrogen form and nitrogen absence on utilization of assimilates for growth and maintenance in tops and roots of Lolium multifiorum. Physiol. Plant. 46:165-168

6. -- , and C. R. Jensen. 1977. Growth and maintenance respiration in whole plant parts, tops, and roots of Lolium multiflorum. Physiol. Plant. 39:155-164

7. Horst, G. L., C. J. Nelson, and K. H. Asay. 1978. Relationship of leaf elongation to forage yield of tall fescue genotypes. Crop Sci. 18:715-719.

8. Jones, R. J., and C. J. Nelson. 1979. Respiration and concentration of water soluble carbohydrate in plant parts of contrasting tall fescue genotypes. Crop Sci. 19:367-372.

9. - - - - , and D. A. Sleper. 1979. Seedling selection for morphological characters associated with yield of tall fescue. Crop Sci. 19:631-634.

10. Kimura, M., Y. Yokoi, and K. Hogetsu. 1978. Quantitative relationships between growth and respiration. II. Evaluation of constructive and maintenance respiration in growing Helianthus tuberosus leaves. Bot. Mag. 91:43-56.

11. Lambers, H. 1979. Efficiency of root respiration in relation to growth rate, morphology, and soil composition. Physiol. Plant. 46:194-202.

12. - -- R. Noord, and F. Posthumus. 1979. Respiration of Senecio shoots: Inhibition during photosynthesis, resistance to cyanide and relation to growth and maintenance. Physiol. Plant. 45:351-356.

13. Matches, A. G. 1969. Influence of cutting height in darkness on measurement of energy reserves of tall fescue. Agron. J. 61:896-898.

14. McCree, K. J. 1970. An equation for the rate of respiration of white clover plants grown under controlled conditions. p. 221-229. In I. Setlik (ed.) Prediction and measurement of photosynthetic productivity (Proc. IBP/PP Technical meeting, Trebon). Centre for Agricultural Publishing and Documentation, Wageningen, Netherlands.

15. --- 1974. Equations for the rate of dark respiration of white clover and grain sorghum, as functions of dry weight, photosynthetic rate, and temperature. Crop Sci. 14:509-514.

16. Nelson, C. J., K. H. Asay, and G. L. Horst. 1975. Relationship of leaf photosynthesis to forage yield of tall fescue. Crop Sci. 15:476478

17. Penning de Vries, F. W. T. 1974. Substrate utilization and respiration in relation to growth and maintenance in higher plants. Neth. J. Agric. Sci. 22:40-44.

18. - - 1975. The cost of maintenance processes in plant cells. Ann Bot. 39:77-92.

19. -..- J. M. Witlage, and D. Kremer. 1979. Rates of respiration and of increase in structural dry matter in young wheat, ryegrass, and maize plants in relation to temperature, to water stress and to their sugar content. Ann. Bot. 44:595-609.

20. Robson, M. J., A. J. Parsons. 1981. Respiratory efflux of carbon dioxide from mature and meristematic tissue of uniculm barley during eighty hours of continuous darkness. Ann. Bot. 48:727-731.

21. Ryle, G. J. A., J. M. Cobby, and C. E. Powell. 1976. Synthetic and maintenance respiratory losses of ${ }^{14} \mathrm{CO}_{2}$ in uniculm barley and maize. Ann. Bot. 40:571-586

22. Smith, D. 1969. Removing and analyzing total non-structural carbohydrates from plant tissues. Wisconsin Agric. Exp. Stn. Res. Bull. 41.

23. Volenec, J. J., and C. J. Nelson. 1982. Diurnal leaf elongation in tall fecsue genotypes. Crop Sci. 22:531-535.

24. Thornley, J. H. M. 1970. Respiration, growth, and maintenance in plants. Nature 227:304-305.

25. --- 1977. Growth, maintenance and respiration: a re-interpretation. Ann. Bot. 41:1191-1203.

26. Wilhelm, W. W., and C. J. Nelson. 1978. Growth analysis of tall fescue genotypes differing in yield and leaf photosynthesis. Crop Sci. 18:951-954

27. Wilson, D. 1975. Variation in leaf respiration in relation to growth and photosynthesis of Lolium. Ann. Appl. Biol. 80:323-338.

28. Yokoi, Y., M. Kimura, and K. Hogetsu. 1978. Quantitative rela tionships between growth and respiration. I. Components of respiratory loss and growth efficiencies of etiolated red bean seedlings. Bot. Mag. 91:31-41

29. Yemm, E. W. 1965. The respiration of plants and their organs. p. 231-310. In F. C. Steward (ed.) Plant physiology: A treatise. Vol. IV A: Metabolism: Organic nutrition and nitrogen metabolism. Academic Press, New York. 